\title{
Nanoparticle Beacons: Supersensitive Smart Materials with On/Off-Switchable Affinity to Biomedical Targets
}

Vladimir R. Cherkasov, Elizaveta N. Mochalova, Andrey V. Babenyshev, Alexandra V. Vasilyeva, Petr I. Nikitin and Maxim P. Nikitin*

*E-mail: max.nikitin@phystech.edu

Table S1. DNA sequences of capture and input oligonucleotides used in the study.

\begin{tabular}{|c|c|c|}
\hline Name & Specificity & Sequence \\
\hline $\begin{array}{l}\text { Capture } \\
\text { B1S }\end{array}$ & $\mathrm{n} / \mathrm{a}$ & 5'-(biotin dT)-AGCTGGGGGAGTATTGCGGAGGGAGGTGA-(C6 thiol)-3' \\
\hline $\begin{array}{l}\text { Capture } \\
\text { B2S }\end{array}$ & $\mathrm{n} / \mathrm{a}$ & 5'-(biotin dT)- AACGCACTTCTGTATTCTACACTTCTGGA-(C6 thiol)-3' \\
\hline $\begin{array}{l}\text { Capture } \\
\text { B3S }\end{array}$ & $\mathrm{n} / \mathrm{a}$ & 5'-(biotin dT)- ATTCCGGGGAGAGTATGGCGGGGAGACTGTCGGA-(C6 thiol)-3' \\
\hline $\begin{array}{l}\text { Capture } \\
\text { B4S }\end{array}$ & $\mathrm{n} / \mathrm{a}$ & 5'-(biotin dT)-ACCTGGGGGAGTATTGCGGAGGGAGGTGA-(C6 thiol)-3' \\
\hline Capture F4S & $\mathrm{n} / \mathrm{a}$ & 5'-(FAM dT)-ACCTGGGGGAGTATTGCGGAGGGAGGTGA-(C6 thiol)-3' \\
\hline $\begin{array}{l}\text { Capture } \\
\text { B4N }\end{array}$ & $\mathrm{n} / \mathrm{a}$ & 5'-(biotin dT)-ACCTGGGGGAGTATTGCGGAGGGAGGTGA-(C6 amine)-3' \\
\hline $\begin{array}{l}\text { Capture } \\
\mathrm{B}(0 \mathrm{~A}) 4 \mathrm{~S}\end{array}$ & $\mathrm{n} / \mathrm{a}$ & 5'-(biotin dT)-TCCTGGGGGAGTATTGCGGAGGGAGGTGA-(C6 thiol)-3' \\
\hline $\begin{array}{l}\text { Capture } \\
\mathrm{B}(2 \mathrm{~A}) 4 \mathrm{~S}\end{array}$ & $\mathrm{n} / \mathrm{a}$ & 5'-(biotin dT)-AACTGGGGGAGTATTGCGGAGGGAGGTGA-(C6 thiol)-3' \\
\hline $\begin{array}{l}\text { Capture } \\
\mathrm{B}(3 \mathrm{~A}) 4 \mathrm{~S}\end{array}$ & $\mathrm{n} / \mathrm{a}$ & 5'-(biotin dT)-AAATGGGGGAGTATTGCGGAGGGAGGTGA-(C6 thiol)-3' \\
\hline Input $1 \mathrm{sp}$ & B1S & TCACCTCCCTCCGCAATACTCCCCCAGCT \\
\hline Input $1 \mathrm{~ns}$ & $\begin{array}{c}\text { non- } \\
\text { specific } \\
(\text { control\#1) }\end{array}$ & CATGAGGGGCGGGGACGCCGCCTGTCT \\
\hline Input $2 \mathrm{~ns}$ & $\begin{array}{c}\text { non- } \\
\text { specific } \\
\text { (control\#2) }\end{array}$ & $\begin{array}{l}\text { CTGTAATCATGGGTTGGTGTGTTGTGGATATTTATTTTCCACATTCAATACC } \\
\text { CT }\end{array}$ \\
\hline Input $2-1 \mathrm{sp}$ & $\mathrm{B} 2 \mathrm{~S}$ & TCCAGAAGTGTAGAATACAGAAGTGCGTT \\
\hline Input $3-1 \mathrm{sp}$ & B3S & TCCGACAGTCTCCCCGCCATACTCTCCCCGGATT \\
\hline Input $4-1 \mathrm{sp}$ & $\begin{array}{l}\text { B4S, F4S, } \\
\text { B(0A)4S, } \\
\text { B(2A)4S, } \\
\text { B(3A)4S }\end{array}$ & TCACCTCCCTCCGCAATACTCCCCCAGGT \\
\hline
\end{tabular}


Table S2. Free energy of the secondary structures of capture DNAs calculated using the NUPACK software $\left(1 \mathrm{M} \mathrm{NaCl}, 25^{\circ} \mathrm{C}\right)$.

\begin{tabular}{|c|c|c|c|c|}
\hline Name & $\begin{array}{l}\text { Single strand } \\
\text { secondary } \\
\text { structure (kcal } \\
\left.\mathrm{mol}^{-1}\right)^{a}\end{array}$ & $\begin{array}{l}\text { Complex with } \\
\text { specific } \\
\text { oligonucleotide } \\
\left(\mathrm{kcal} \mathrm{mol}^{-1}\right)\end{array}$ & $\begin{array}{l}\text { Complex with non- } \\
\text { specific } \\
\text { oligonucleotide } 1 \mathrm{~ns} \\
\quad\left(\mathrm{kcal} \mathrm{mol}^{-1}\right)\end{array}$ & $\begin{array}{l}\text { Complex with non- } \\
\text { specific } \\
\text { oligonucleotide } 2 \mathrm{~ns} \\
\left(\mathrm{kcal} \mathrm{mol}^{-1}\right)\end{array}$ \\
\hline B1S & -0.30 & -50.40 & (no hybridization) & (no hybridization) \\
\hline B2S & -1.10 & -44.80 & (no hybridization) & (no hybridization) \\
\hline B3S & -2.75 & -57.07 & (no hybridization) & (no hybridization) \\
\hline B4S, B4N, F4S & -2.04 & -50.22 & (no hybridization) & (no hybridization) \\
\hline $\mathrm{B}(0 \mathrm{~A}) 4 \mathrm{~S}$ & -1.58 & -49.76 & (no hybridization) & (no hybridization) \\
\hline $\mathrm{B}(2 \mathrm{~A}) 4 \mathrm{~S}$ & -1.45 & -48.20 & (no hybridization) & (no hybridization) \\
\hline $\mathrm{B}(3 \mathrm{~A}) 4 \mathrm{~S}$ & -0.10 & -45.56 & (no hybridization) & (no hybridization) \\
\hline
\end{tabular}

${ }^{a}$ Data shown for the folding structure with the lowest computed $\Delta \mathrm{G}$. 
Table S3. AuNP:B4S SM specificity to the input DNA of different sizes and complementarity (LFA format with anti-biotin strips).

\begin{tabular}{|c|c|c|c|c|c|}
\hline $\begin{array}{l}\text { Specificity } \\
\text { Test DNA } \\
\text { (stDNA)\# }\end{array}$ & $\begin{array}{l}\text { Input DNA sequence, } 5^{\prime}-3^{\prime} \\
\text { (mismatches are shown in } \\
\text { red underlined letters) }\end{array}$ & $\begin{array}{l}\text { DNA } \\
\text { length } \\
(\mathrm{nt})\end{array}$ & $\begin{array}{l}\text { Optical Signal } \\
\text { for } 1 \mathrm{nM} \text { Input } \\
\text { DNA } \\
\text { Concentration } \\
\text { (a.u.) }\end{array}$ & $\begin{array}{l}\text { Theoretical } \\
\text { Fraction in } \\
\text { Complex } \\
(\text { for } 1 \mathrm{nM})^{\boldsymbol{a}}\end{array}$ & Rem. \\
\hline & \multicolumn{5}{|c|}{ Fully complementary input } \\
\hline stDNA\#1 & $\begin{array}{l}\text { TCACCTCCCTCCGCAATACTCCCCC } \\
\text { AGGT }\end{array}$ & 29 & $185 \pm 4$ & 1.00 & $\begin{array}{c}\text { Positive } \\
\text { control } \\
\text { (fully compl. } \\
\text { DNA) } \\
\end{array}$ \\
\hline & \multicolumn{5}{|c|}{ Non-complementary input } \\
\hline stDNA\#2 & $\begin{array}{l}\text { GATCGGGCGTCTGTCTTGCACTCT } \\
\text { TGATTTCTGGAGACCACAAGTT }\end{array}$ & 49 & $6 \pm 2^{* * b}$ & 0.00 & \\
\hline stDNA\#3 & $\begin{array}{l}\text { CTGTAATCATGGGTTGGTGTGTTG } \\
\frac{\text { TGGATATTTATTTTCCACATTCAA }}{\text { TACCCT }}\end{array}$ & 54 & $1 \pm 1 * *$ & 0.00 & \\
\hline stDNA\#4 & $\begin{array}{l}\text { TACATGGACGGGGAGTATTGCGG } \\
\underline{\underline{\text { AGGGAG }}}\end{array}$ & 29 & $1 \pm 2^{* *}$ & 0.00 & \\
\hline & \multicolumn{5}{|c|}{ Inputs with different levels of complementarity } \\
\hline stDNA\#5 & $\begin{array}{l}\text { CCTCCAATGGGCAGGAAAACAGAT } \\
\underline{\text { CCTAGA }}\end{array}$ & 30 & $13 \pm 8^{* *}$ & 0.00 & \\
\hline stDNA\#6 & $\begin{array}{l}\text { ATTCAATACCCTA्CGAATTTACTCT } \\
\underline{\text { AATCATGGGTTG }}\end{array}$ & 37 & $12 \pm 3^{* *}$ & 0.01 & \\
\hline stDNA\#7 & $\begin{array}{l}\text { TCTCCATCTCCACATTCAATACCCT } \\
\underline{\underline{\mathrm{ACG}}}\end{array}$ & 28 & $16 \pm 3 * *$ & 0.04 & \\
\hline stDNA\#8 & $\begin{array}{l}\text { TCACCATCCTAACTCCCTCCGCAAT } \\
\text { ACTC }\end{array}$ & 29 & $28 \pm 2 * *$ & 1.00 & \\
\hline stDNA\#9 & $\begin{array}{l}\text { TCACCACCCTCCGCATATCTCCCCC } \\
\text { AGGT }\end{array}$ & 29 & $173 \pm 7$ & 1.00 & \\
\hline & \multicolumn{5}{|c|}{ Single Nucleotide Polymorphism, 29 nt } \\
\hline stDNA\#10 & $\begin{array}{l}\text { TCACCTCCCTCCGCAATACTCCCCC } \\
\text { AGㅁT }\end{array}$ & 29 & $64 \pm 6^{* *}$ & 1.00 & \\
\hline stDNA\#11 & 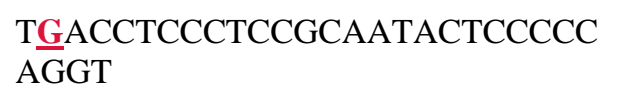 & 29 & $122 \pm 7^{* *}$ & 1.00 & \\
\hline stDNA\#12 & $\begin{array}{l}\text { TCACCTCCCTCCGCTATACTCCCCCA } \\
\text { GGT }\end{array}$ & 29 & $160 \pm 1^{*}$ & 1.00 & \\
\hline & \multicolumn{5}{|c|}{ Single Nucleotide Polymorphism, $15 \mathrm{nt}$} \\
\hline stDNA\#13 & TCCGCAATACTCCCC & 15 & $160 \pm 7$ & 1.00 & \\
\hline stDNA\#14 & TCCㅡㄷAATACTCCCC & 15 & $105 \pm 10^{*}$ & 0.90 & \\
\hline stDNA\#15 & TCCGCAATACTGGCC & 15 & $67 \pm 7 * *$ & 0.95 & \\
\hline
\end{tabular}




\begin{tabular}{|c|c|c|c|c|c|}
\hline stDNA\#16 & TCCGCAAAACTCCCC & 15 & $157 \pm 7$ & 0.97 & \\
\hline \multicolumn{6}{|c|}{ Endonuclease Cleaved DNA of Phage $\lambda, 10 \mathrm{mg} / \mathrm{L}$} \\
\hline $\begin{array}{c}\text { Phage } \lambda \\
\text { DNA + } \\
\text { Alu I }\end{array}$ & Restriction endonuclease Alu I & & $4.0 \pm 1.0$ & $\mathrm{n} / \mathrm{a}$ & $\begin{array}{l}\text { Recognition } \\
\text { site: } \\
\text { AG } \uparrow C T \\
\text { TC } \downarrow \text { GA }\end{array}$ \\
\hline $\begin{array}{c}\text { Phage } \lambda \\
\text { DNA + } \\
\text { HpySE526 } \\
\text { I }\end{array}$ & Restriction endonuclease HpySE526 I & & $6.7 \pm 1.5$ & $\mathrm{n} / \mathrm{a}$ & $\begin{array}{l}\text { Recognition } \\
\text { site: } \\
\mathrm{A} \uparrow \mathrm{CGT} \\
\mathrm{TGC} \downarrow \mathrm{A}\end{array}$ \\
\hline $\begin{array}{l}\text { Phage } \lambda \\
\text { DNA } \\
+ \text { Fai I } \\
\end{array}$ & Restriction endonuclease Fai I & & $4.3 \pm 1.5$ & $\mathrm{n} / \mathrm{a}$ & $\begin{array}{l}\text { Recognition } \\
\text { site: } \\
\text { YA } \uparrow \text { TR } \\
\text { RT } \downarrow A Y\end{array}$ \\
\hline
\end{tabular}

${ }^{a}$ NUPACK data, $25^{\circ} \mathrm{C}, 1 \mathrm{M} \mathrm{Na}^{+}$, concentration of components: $1 \mathrm{nM}$

$\boldsymbol{b}$ Statistically significant difference: $* \mathrm{P}<0.05, * * \mathrm{P}<0.01$ (two-tailed unpaired Student $t$-test) 
(a)

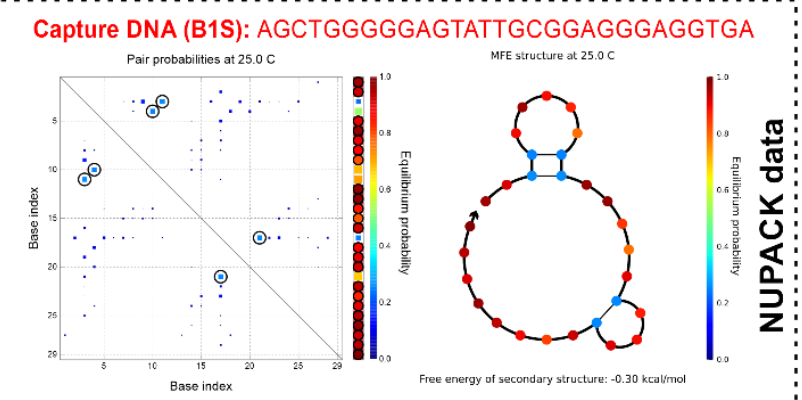

Free energy of ordered complex $(: K T \log Q)$ : $1.84 \mathrm{kcal}$.

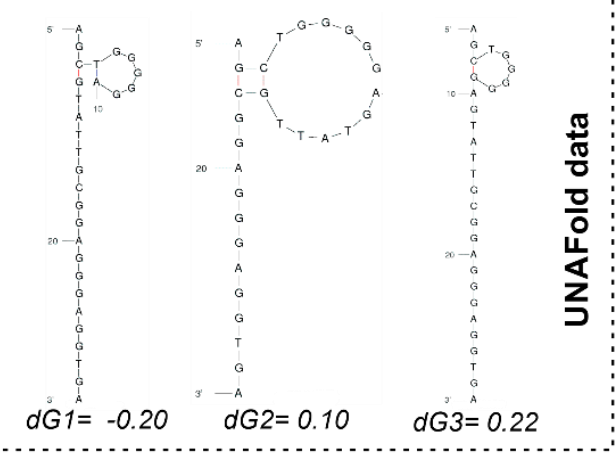

(b) Capture DNA (B2S): AACGCACTTCTGTATTCTACACTTCTGGA
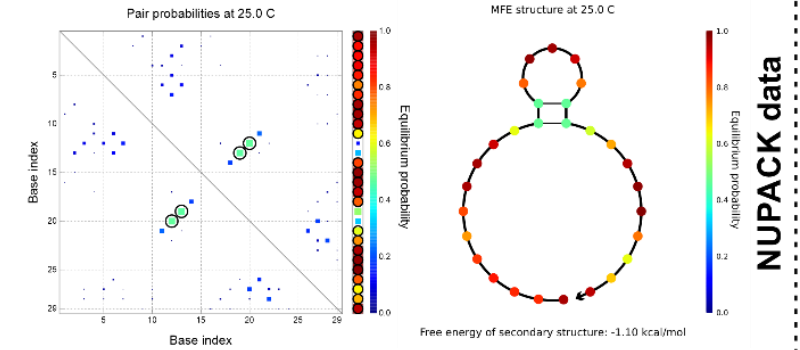

Free energy of ordered complex $(-k T \log Q) \cdot 2.48$ kcalimal

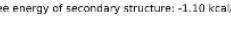

.

$d G \hat{1}=-1.10 \quad \hat{G} \hat{G}=-1.08 \quad d G \hat{3}=-0.86$

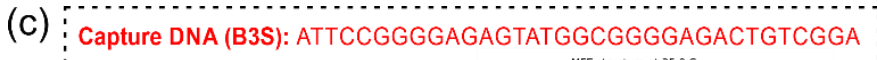

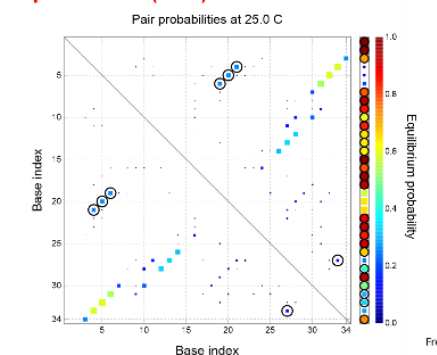

Free energy of ordered complex $(-k T \log Q):-4.34 \mathrm{kcal} / \mathrm{mol}$

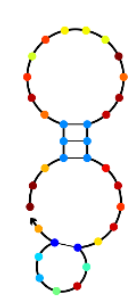

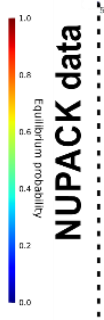

(d) $\quad$ Capture DNA (B4S): ACCTGGGGGAGTATTGCGGAGGGAGGTGA

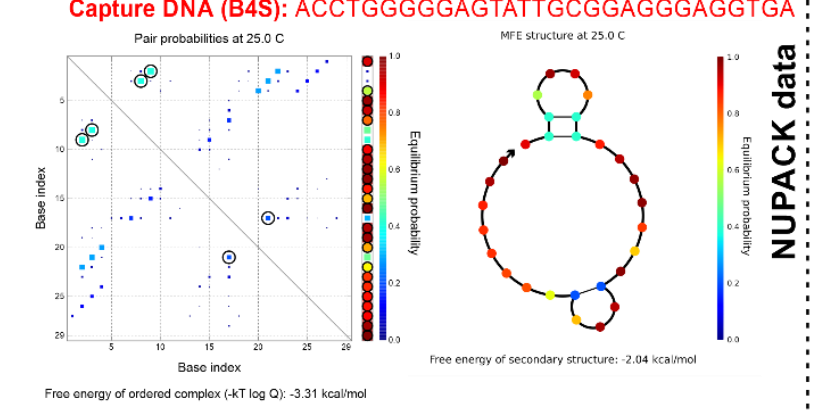

$d G 1=-2.76 \quad d G 2=-2.51 \quad d G 3=-1.93$
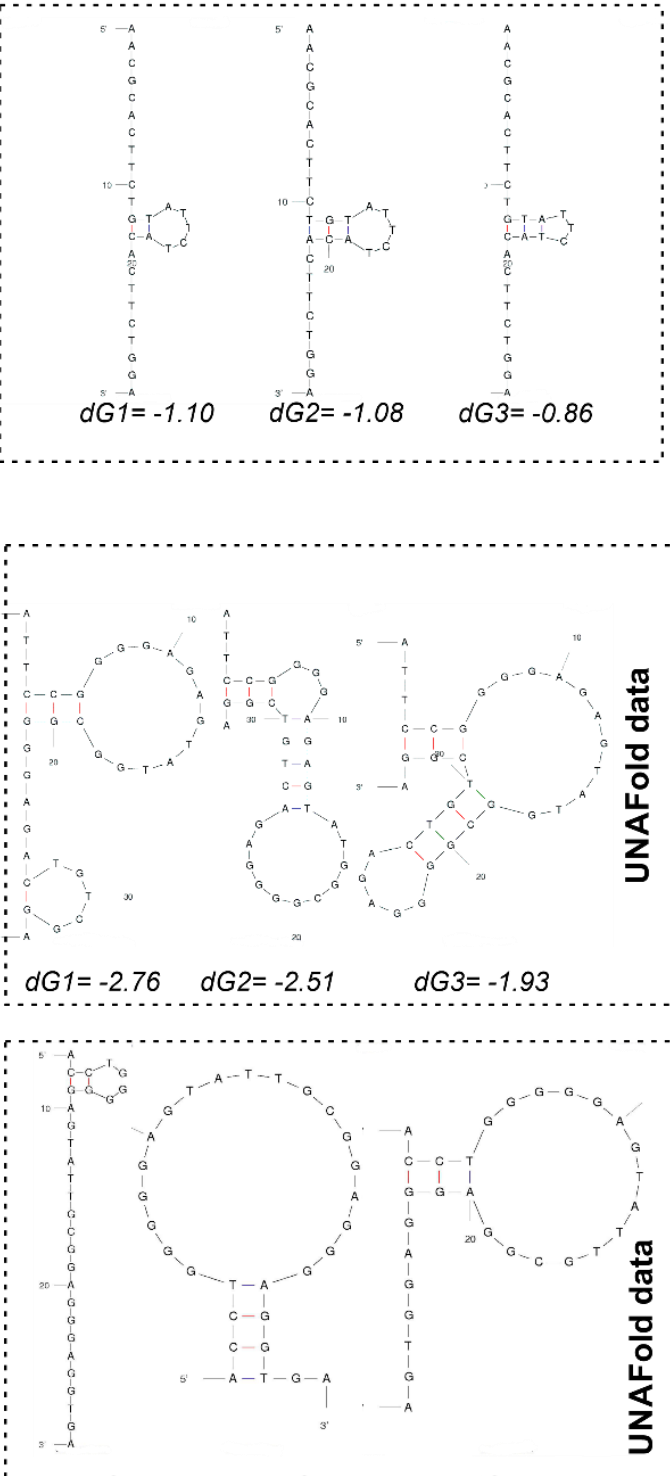
(e)

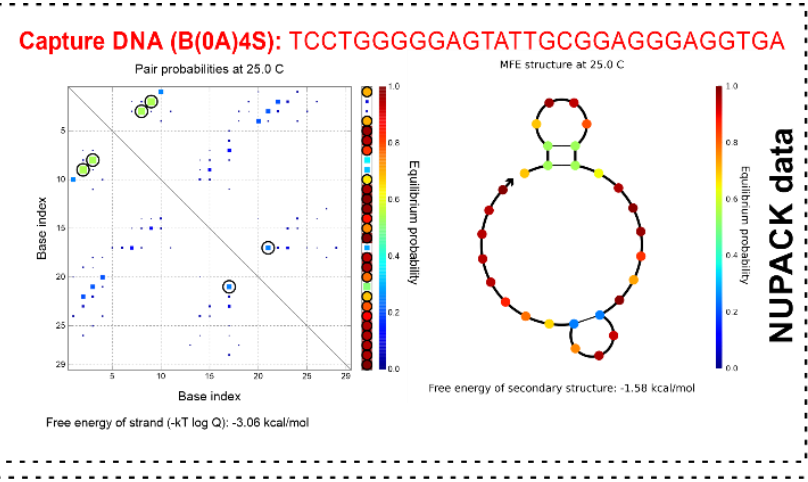

(f)

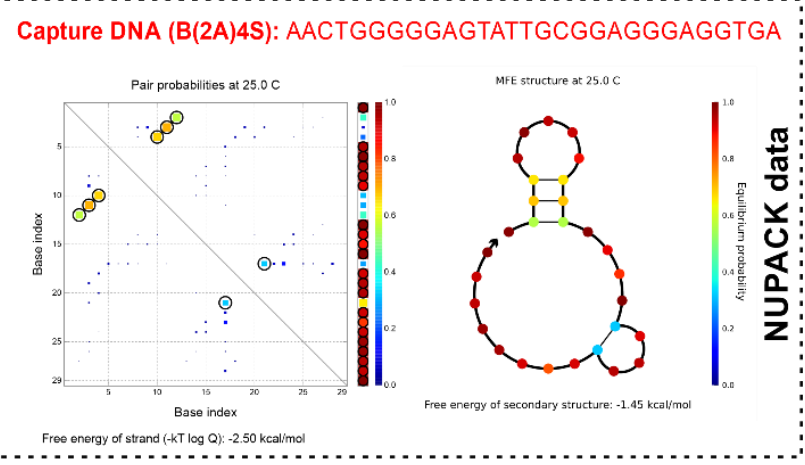

(g)

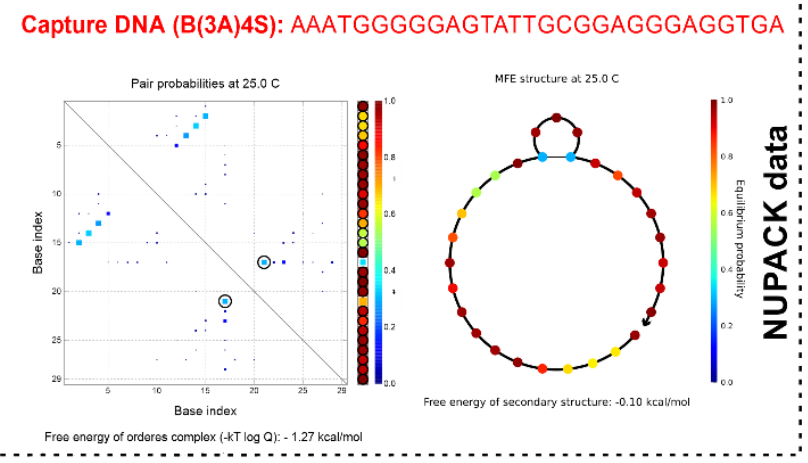

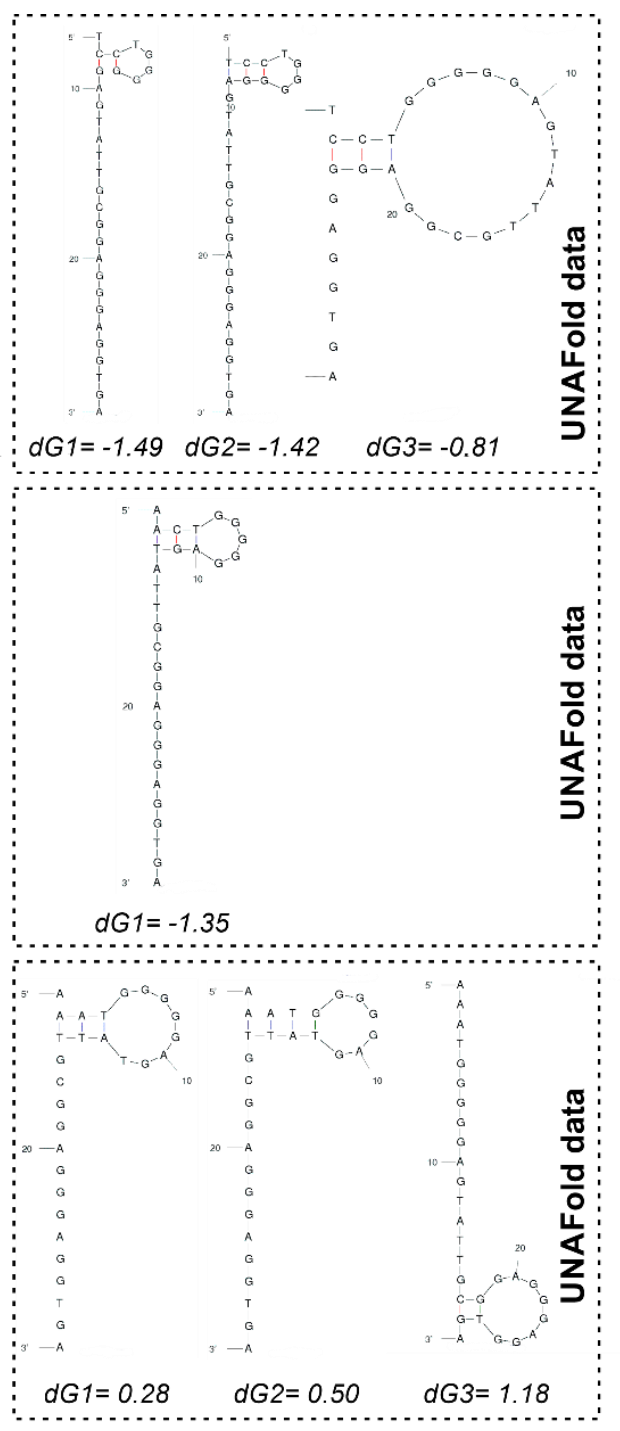

Figure S1. Folding of capture DNA simulated in NUPACK and UNAFold software (conditions: $\left.1 \mathrm{M} \mathrm{NaCl}, 25{ }^{\circ} \mathrm{C}\right)$. 


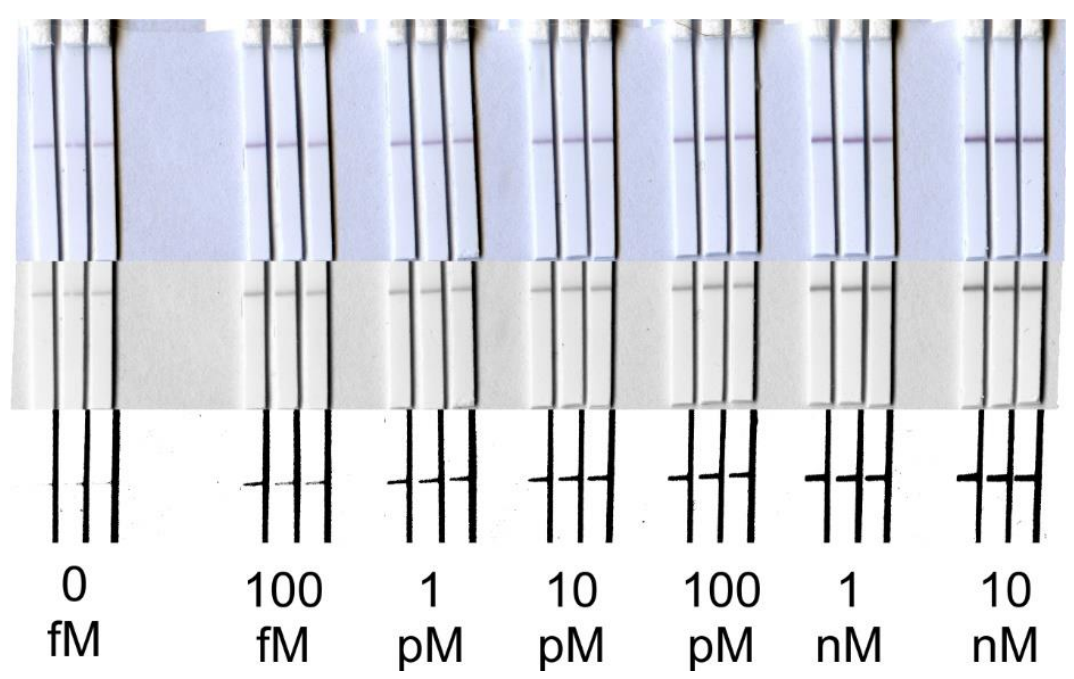

Figure S2. Verification of SM reproducibility. Scanned photographs of the LFA strips (top raw image, middle - b/w image, bottom - contrast/brightness-optimized image during ImageJ processing). 


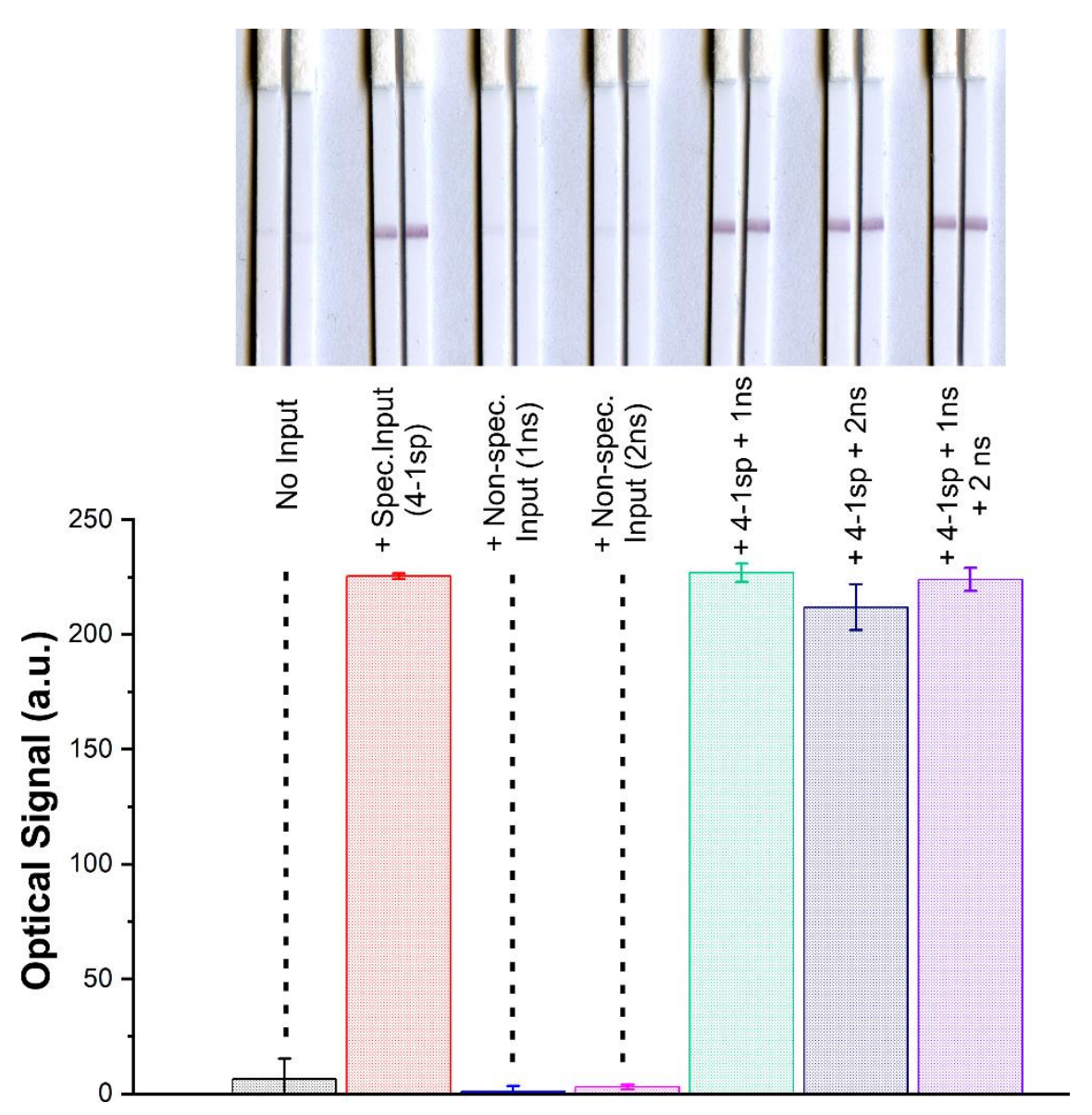

Figure S3. Verification of SM specificity to the input DNA. Lateral flow assay performance of AuNP:B4S mixed with various specific and non-specific inputs: (top) photographs of LFA test strips, (bottom) ImageJ quantification of SM binding with streptavidin test line. Concentration of input oligonucleotides $-0.1 \mu \mathrm{M}$. 


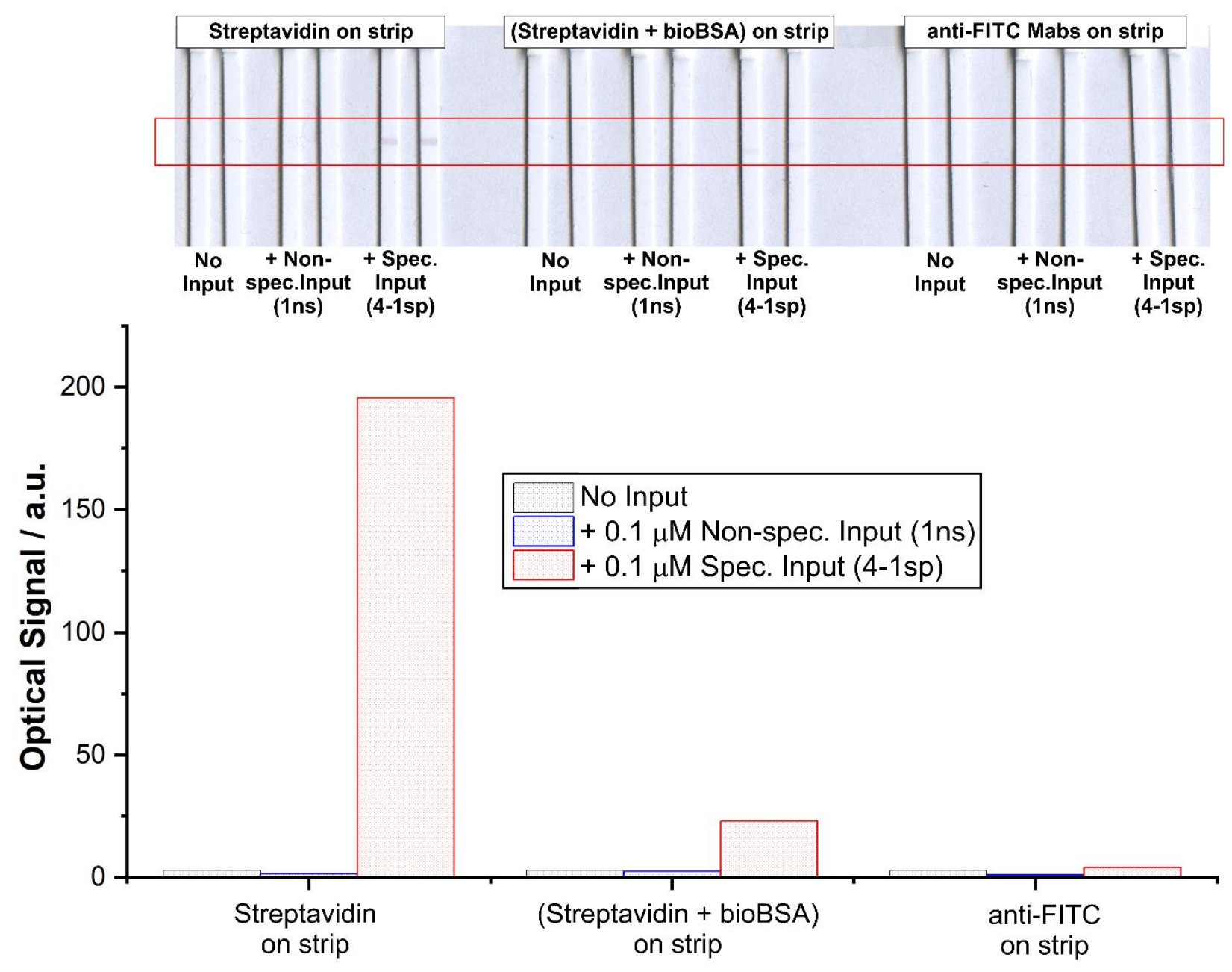

Figure S4. Verification of SM specificity to the target. AuNP:B4S binding with biotin ligands on LFA strips - streptavidin, streptavidin blocked with biotin-BSA conjugate (bioBSA) and antiFITC Mabs): (top) photographs of LFA strips, (bottom) ImageJ quantification of SM binding with test line. Concentration of inputs oligonucleotides $-0.1 \mu \mathrm{M}$. 


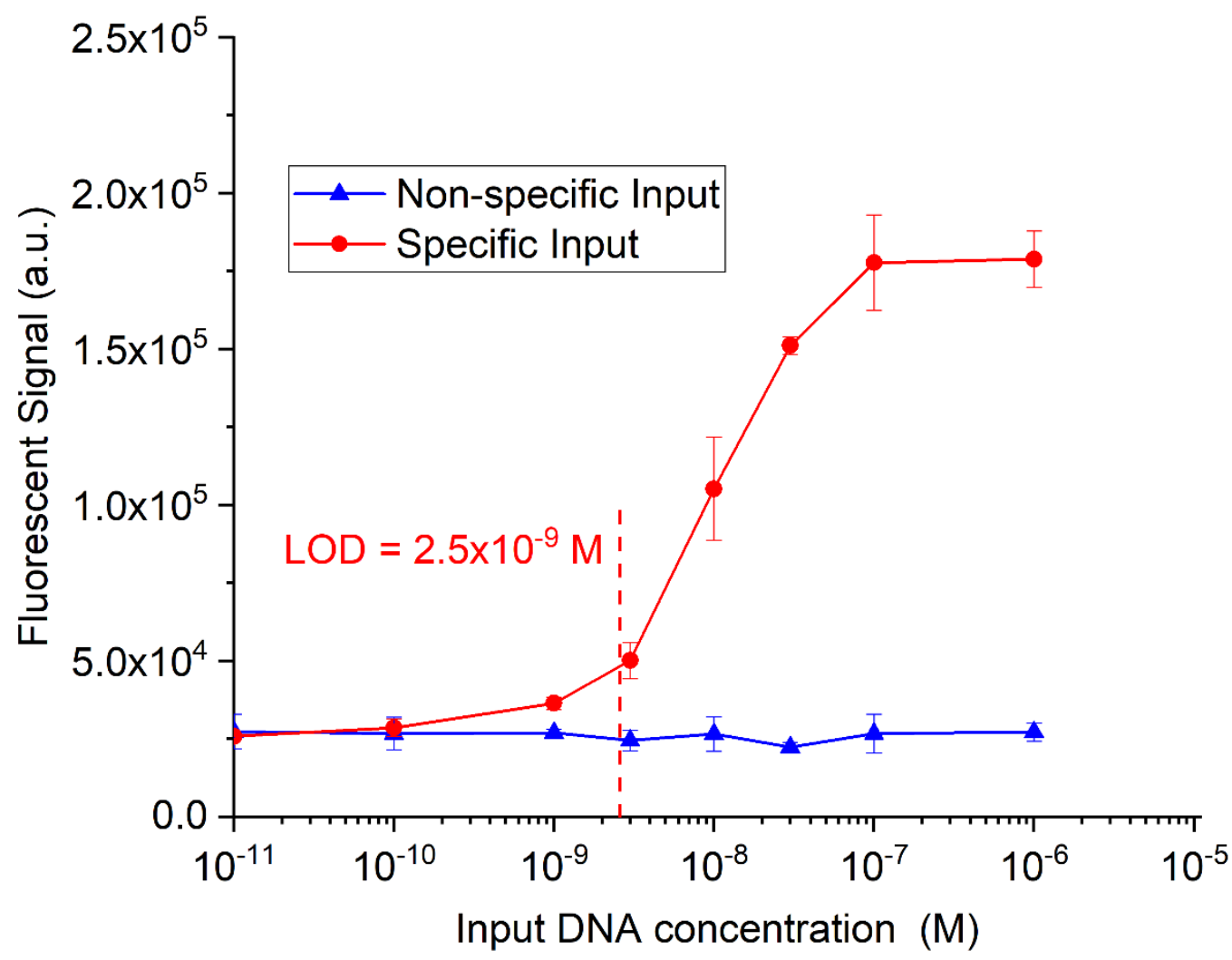

Figure S5. Verification of the fluorescent analog of B4S (5'- Cy3, 3'- BHQ2) capture DNA functionality in reaction with specific (4-1sp) and non-specific (1ns) Input DNA as a molecular beacon in corresponding reaction conditions (the beacon conc. $10^{-8} \mathrm{M}, 10 \mathrm{mM}$ phosphate buffer $\mathrm{pH} 7.4,1 \mathrm{M} \mathrm{NaCl}, 0.5 \%$ skimmed milk). 
(a)

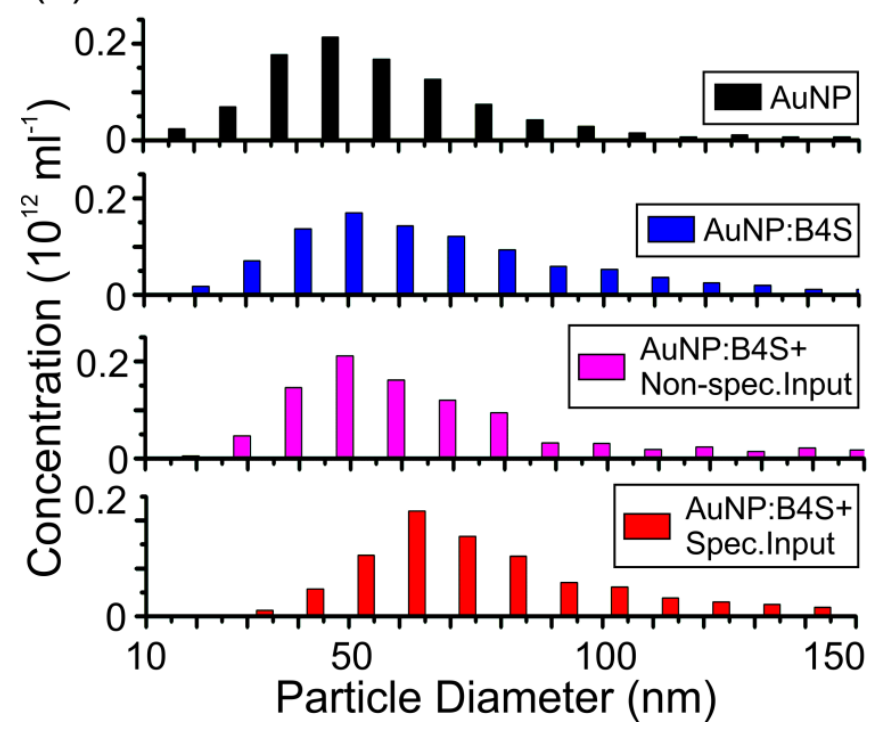

(b)

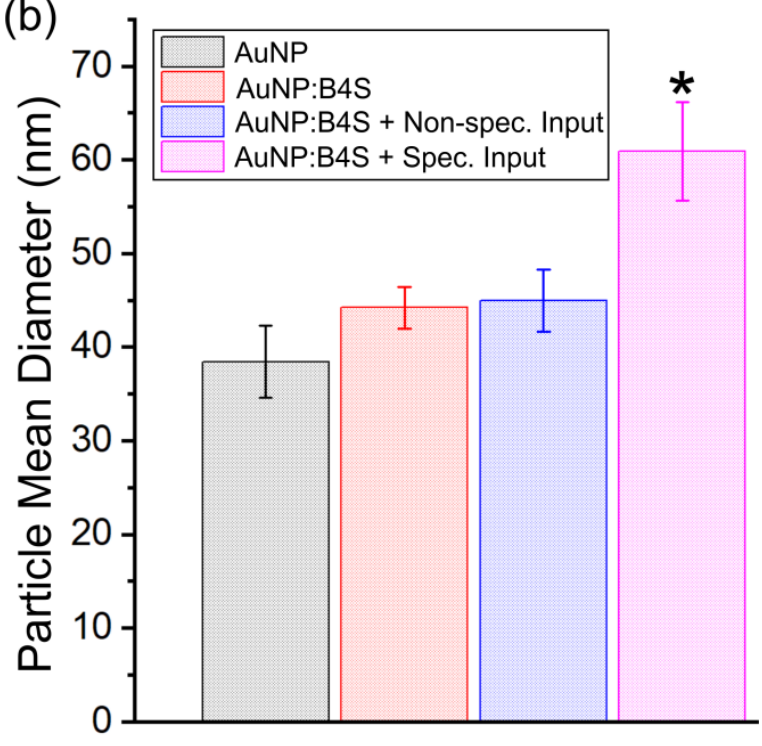

Figure S6. Nanoparticle Tracking Analysis (NanoSight, Malvern Instruments Ltd., UK) of hydrodynamic diameter of the AuNP:B4S conjugates before and after addition of the specific (41sp) and non-specific (1ns) input DNA: (a) raw data of particle size distribution; (b) mean complex diameter. Asterisks indicate the significance level of the difference $(* \mathrm{P}<0.01$, twotailed unpaired Student $t$-test) between signal and control (AuNP:B4S without input DNA). 


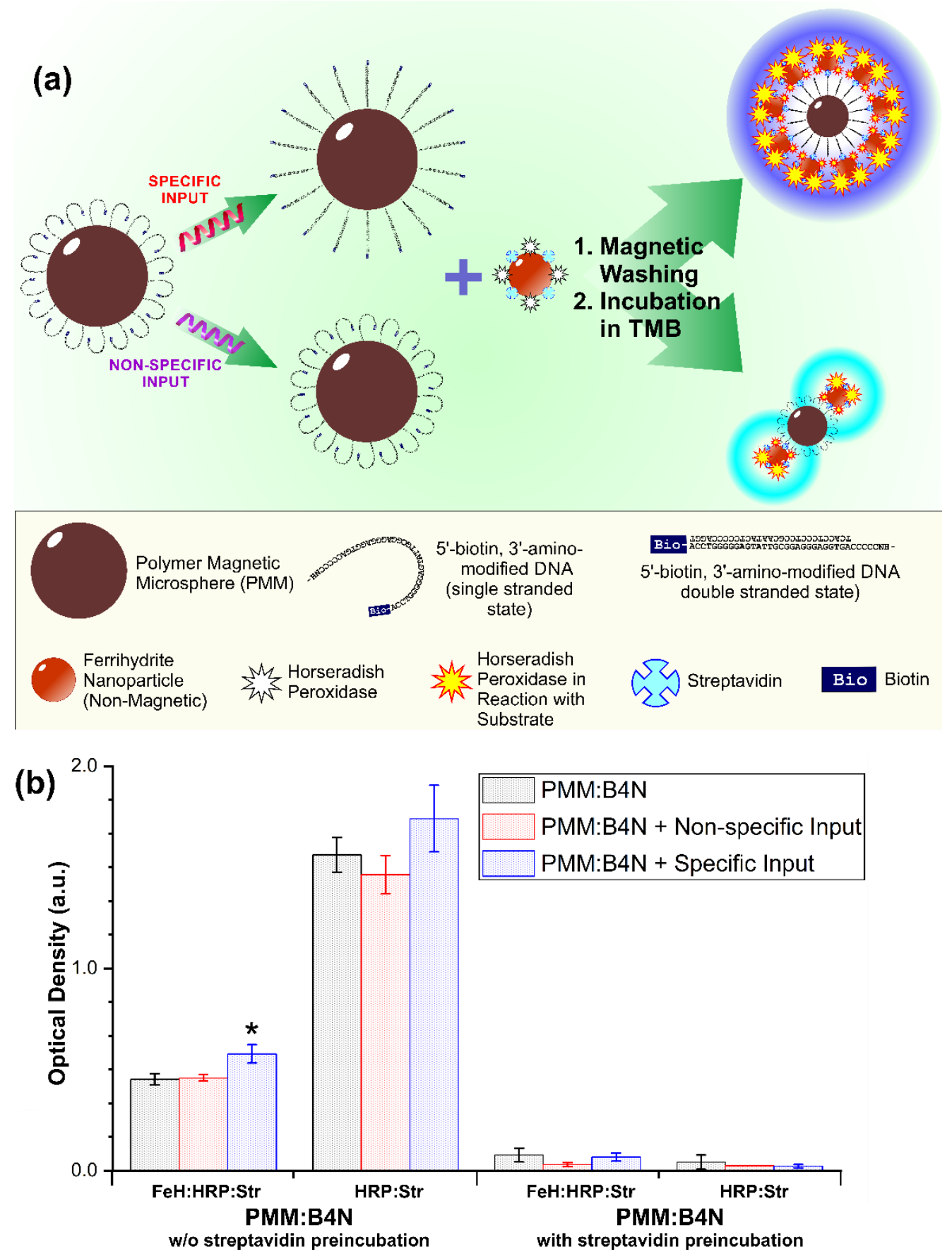

Figure S7. Testing of the masking effect of the terminal DNA-bound biotin on the surface of polystyrene-coated magnetic microspheres (PMM). (a) General scheme of the assay. (b) Interaction of PMM functionalized with 5'-biotin, 3'-amino-modified B4N capture DNA with various targets (FeH-HRP:Str nanoparticles and molecular HRP-Str conjugate) depending on presence of specific (4-1sp) or non-specific (1ns) input DNA and blocking of the reaction by preincubation of the agents with excess of molecular streptavidin. Asterisks indicate the significance level of the difference $(* \mathrm{P}<0.05$, two-tailed unpaired Student $t$-test) within each group between signal and control (PMM:B4N without input DNA). 


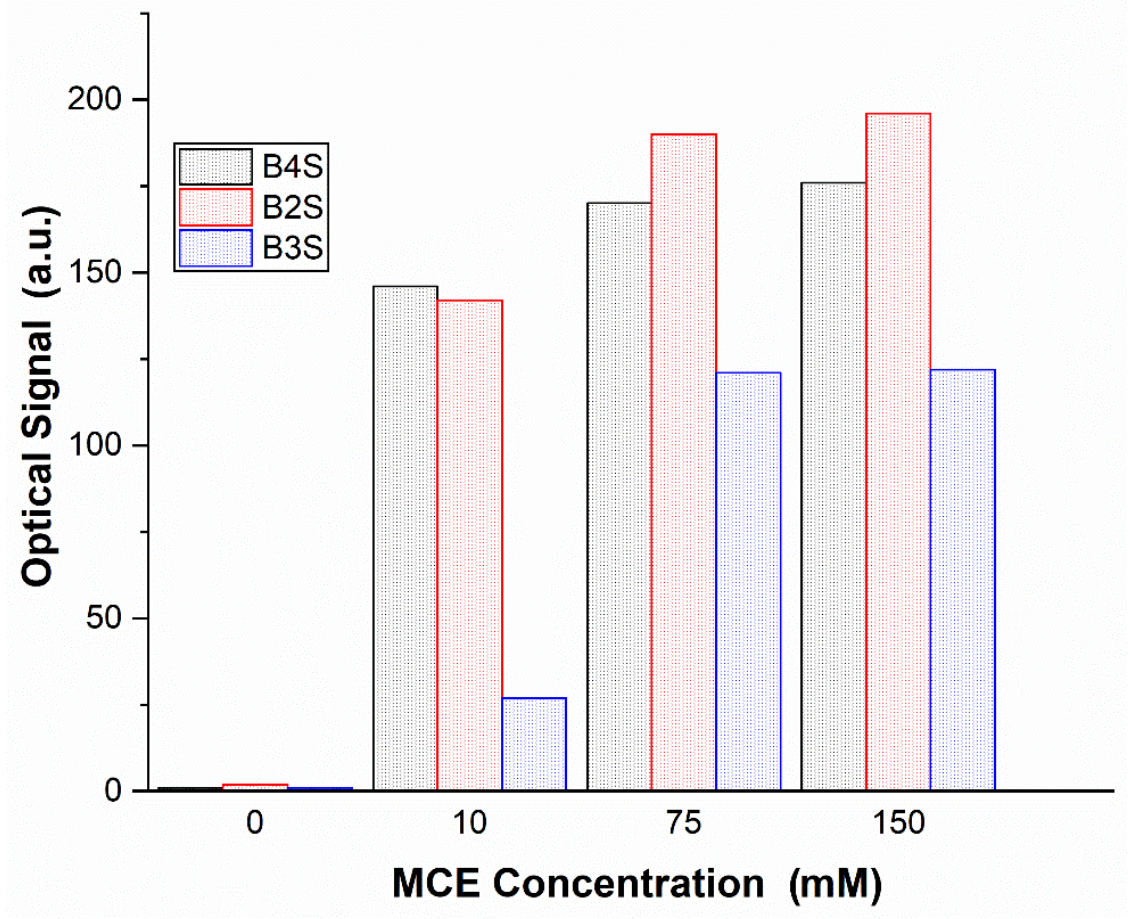

Figure S8. Influence of mercaptoethanol (MCE) on the SM operation in lateral flow assay (streptavidin on the test line; no DNA input added) for AuNP conjugated with three different capture DNA (B4S; B2S; B3S). 

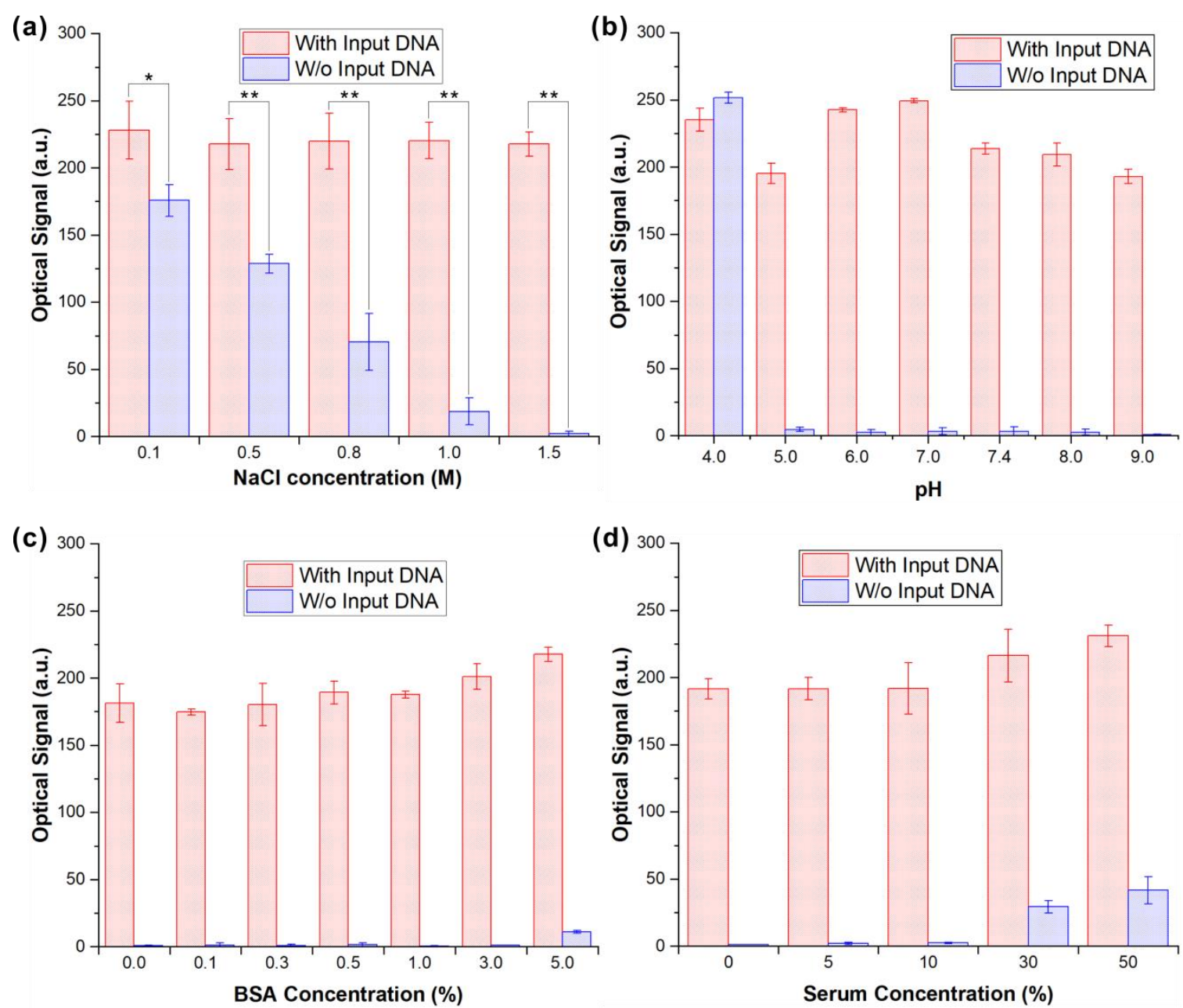

Figure S9. Influence of various parameters of the media on the AuNP:B4S operation in lateral flow assay (streptavidin on the test line, $10^{-8} \mathrm{M}$ input DNA 4-1sp). (a) Effect of ionic strength: different $\mathrm{NaCl}$ content in $10 \mathrm{mM}$ phosphate buffer $\mathrm{pH}$ 7.4. Asterisks indicate significant difference: two-tailed unpaired Student $t$-test, $* \mathrm{P}<0.05, * * \mathrm{P}<0.01$. (b) Effect of $\mathrm{pH}$ at $0.15 \mathrm{M}$ $\mathrm{NaCl}: \mathrm{pH}$ 5-7 - $10 \mathrm{mM}$ phosphate buffers; $\mathrm{pH} 4-0.1 \mathrm{M}$ phosphate-citrate; $\mathrm{pH} 8-9-10 \mathrm{mM}$ borate buffers. (c-d) Effect of protein levels: different concentration of bovine serum albumin (c) and mouse pooled serum concentration (d) in $10 \mathrm{mM}$ phosphate buffer $\mathrm{pH} 7.4,1 \mathrm{M} \mathrm{NaCl}$. 


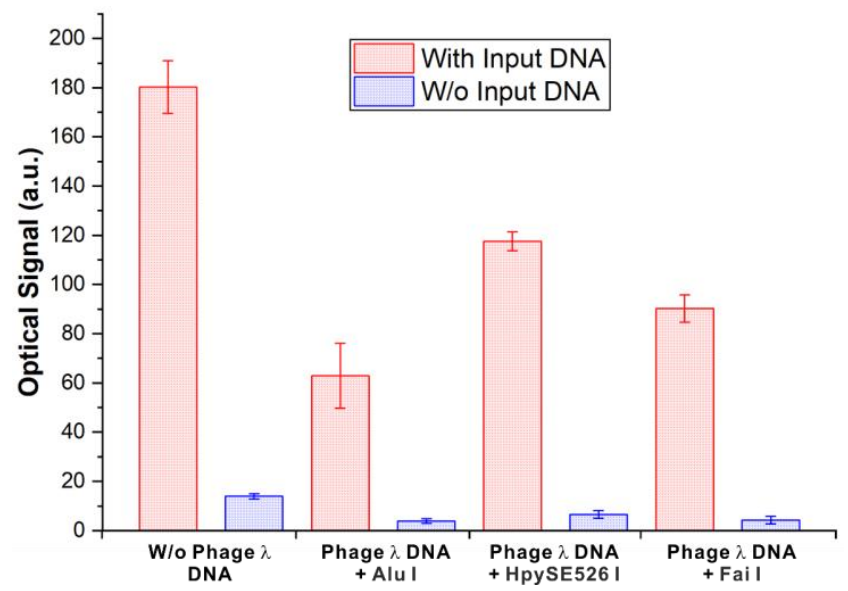

Figure S10. Influence of phage $\lambda$ DNA (10 mg/L, 31.5 MDa) cleaved by Alu I, HpySE526 I, and Fai I endonucleases on the AuNP:B4S SM operation in lateral flow assay (streptavidin on the test line, $10^{-9} \mathrm{M}$ input DNA 4-1sp, measurements in $10 \mathrm{mM}$ phosphate buffer $\mathrm{pH} 7.4,1 \mathrm{M}$ $\mathrm{NaCl})$. 


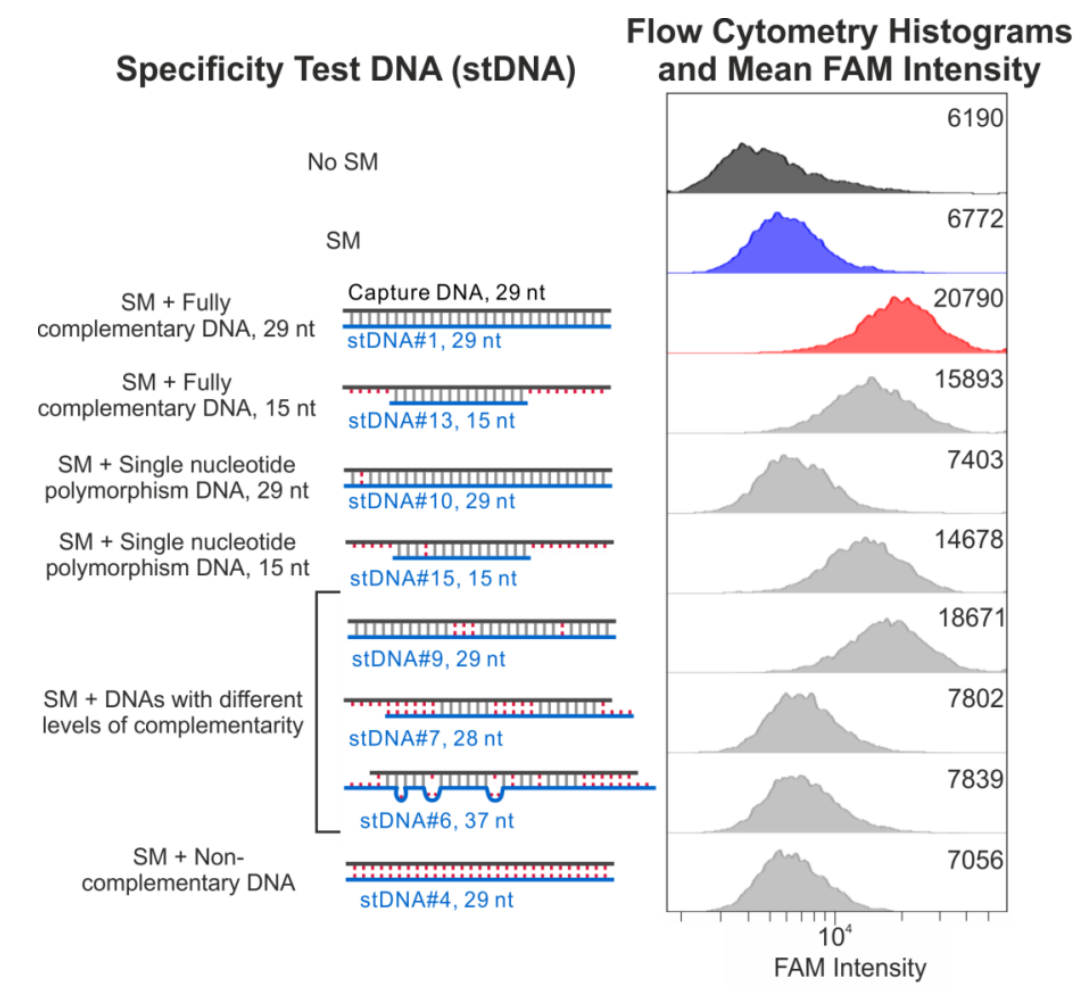

Figure S11. AuNP:B4S:F4S SM specificity to input DNA in the cell-targeting assay. Flow cytometry FAM channel histograms demonstrate agent binding with HER2/neu-positive (SKBR-3) cells via the streptavidin-trastuzumab (anti-HER2/neu antibody) conjugate in response to input DNA of various lengths and complementarity to the capture DNA (see sequences in Table S3). 

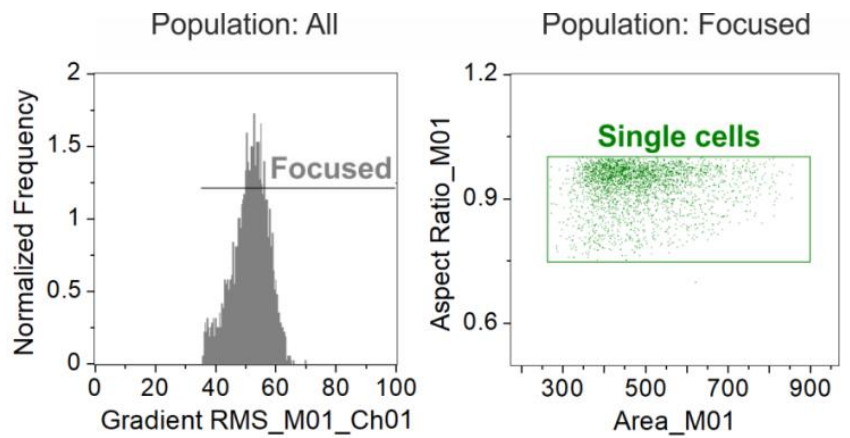

Figure S12. Gating strategy for the imaging flow cytometry experiments with input-dependent specific targeting of cells (an example is shown for the SK-BR-3 cell sample with AuNP:B4S:F4S SM preincubated with fully complementary input DNA). 